\title{
A IMPORTÂNCIA DO PRINCÍPIO DA ESTRITA LEGALIDADE PARA O DIREITO TRIBUTÁRIO
}

\section{Josycler Aparecida Arana Santos*}

SUMÁRIO: 1. Introdução. 2. Conceito jurídico de princípio. 3. Função estrutual dos principios constitucionais. 4. Principios constitucionais tributários. 5. Do princípio da legalidade. 6. A estrita legalidade em matéria tributária. 7. Conclusäo. 8. Bibliografia.

SUMMARY: 1. Introduction. 2. Juridical concept of principle. 3.Structural function of the constitutional principles. 4. Tributary constitutional principles. 5. Of the beginning of the legality. 6.The strict legality in tributary issue. 7. Conclusion. 8. Biography.

SUMARIO: 1.Introducción. 2. Concepto jurídico de princípio. 3. Función estructural de los principios constitucionales. 4. Principios constitucionales tributários. 5. Del princípio de la legalidad. 6. La estricta legalidad en matéria tributária. 7. Conclusion. 8. Bibliografia.

RESUMO: O presente artigo visa apresentar a importancia do Principio da Estrita legalidade para o Direito Tributário, o qual encontra-se previsto no art. 150, I da atual Constituição Federal. Este principio é o alicerce de todo o direito tributário, pois todos os outros principios subsumem-se a partir do mesmo. $O$ estudo desenvolvese a partir da análise douttinária do conceito juridico de princípio, evoluindo para o estudo da localização do mesmo na Carta Magna, e diferenciando entre este e o Principio da Legalidade genérico que se encontra insculpido no art. $5^{\text {a }}$ inciso II da Constituição Federal.

ABSTRACT: The current atticle aims to present the importance of the principle of the strict legality for the tributary Law which is in accordance with the article 150 I, of the current Federal Constitution. This principle is the foundation of the whole tributary law, for all the other principles subsume under the one cited above. The study develops using the doctrinaire analysis of the juridical concept of principle, evolving to the study of the localization of it in the 
Magna Carta, and differing between this one and the generic Principle of the legality that is found in the article 5 - II of the Federal Constitution.

RESUMEN: El presente articulo tiene por objeto presentar la importancia del Principio de la Estricta legalidad para el Derecho Tributario, el cual se encuentra previsto en el art. 150, I de la actual Constitución Federal. Este princípio es la base de todo el derecho tributário pues todos los otros principios se derivan del mismo. El estudio se desarrolla a partir del análisis doctrinal del concepto juridico de princípio, evolucionando hacia el estudio de la localización del mismo en la Carta Magna, y diferenciando entre éste y el Principio de legalidad genérico que se encuentra incluído en el art. 5o, apartado II de la Constitución Federal.

PALAVRASCHAVES: Direito inbutánio. Princípios. Principio da estrita legalidade.

KEY-WORDS: Tributary Law. Principles. Principle of the strict legality.

PALABRAS-LLAVES: Derecho tributario Princípios. Princípio de la estricta legalidad.

\section{Introdução}

Desde o nascimento até sua morte, a pessoa humana, direta ou indiretamente, está sujeita ao pagamento de tributos exigidos pelo Estado com a finalidade de manter e sustentar a máquina estatal.

Raros os fatos da existência em sociedade que não são tributados pelo Estado, pois para que este exerça suas funções inerentes, impõe a cobranças de tributos necessários a sua manutenção.

Como forma de proteger a pessoa do uso arbitrário do poder coercitivo do Estado, a Constituição Federal de 1988 erigiu o Princípio da Legalidade em cláusula pétrea, colocando-o na categoria dos direitos e garantias fundamentais individuais.

O Princípio da Legalidade, em termos absolutos, esta proclamado no art. $5^{\text {a }}$, II da Constituição. Em matéria tributária, o Legislador Constituinte reforça o pressuposto da essencialidade da utilização dos meios legais para a criação e arrecadação de tributos ao editar o art. 150, I do mesmo diploma.

Este artigo institui o Princípio da Estrita Legalidade Tributária, por condicionar a validade da lei que institui ou majora todo e qualquer tributo à fiel observância de todos os passos previstos para a aprovação, pelo Poder Legislativo, de lei tributária, devendo a mesma ser revestida de 
um duplo sentido: material (lei escrita), e formal (fundamentando e restringindo as hipóteses de incidência tributária).

Tanto é verdade tal assertiva, que a constatação da infringência deste princípio acarreta nulidade absoluta de todos os atos a ele não vinculados.

O mesmo tema é objeto de regulamentação pelo legislador, quando da formulação do art. $9^{a}$ do Código Tributário Nacional que repete a redação dada na Constituição, ressalvando apenas a majoração nos casos de ajuste dos mesmos aos objetivos da política cambial, de comércio exterior ou monetária.

O objetivo deste trabalho é analisar o Princípio da Legalidade, como basilar do ordenamento jurídico brasileiro, e por consequêencia um dos mais importantes princípios do Direito Tributário.

Inicia-se a análise do tema proposto através da noção jurídica do que seja princípio, ressaltando a importância vital do entendimento deste conceito para aplicação e utilização das normas juridicas materiais existentes.

Num segundo momento ressalta-se a importância dos princípios constitucionais na formação da estrutura do Direito pátrio, posto que nosso país rege-se por uma Constituição rígida e determinaremos quais são os princípios constitucionais que se aplicam, especificadamente, à matéria tributária.

Em seguida, demostra-se a profunda importância do Princípio da Estrita Legalidade delimitado no art. 150,I da Constituição Federal, para o Direito tributário e no que este se diferencia do Principio da Legalidade, descrito no art. $5^{\text {a }}$,II, da Magna Carta.

Ainda sobre o tema, elenca-se os requisitos indispensáveis para a validade da norma tributária.

Por fim, procurando apresentar uma síntese dos conceitos delineados, demostra-se a importância do Princípio da Estrita Legalidade, como forma de proteção do cidadão frente a ações arbitrárias do Estado e para a própria manutenção do Estado Democrático de Direito, essencial para a real vivência da liberdade tanto individual quanto coletiva da Nação.

\section{Conceito jurídico de princípio}

No estudo do Direito, mais acentuadamente do que em outras ciências, é importante conhecer os princípios essenciais, pois, tendo-se em vista que os princípios jurídicos se encontram relacionados à formação da estrutura material das normas aplicadas no cotidiano das pessoas, o que denominamos Sistema Jurídico. 
Segundo Carraza ${ }^{1}$, sistema pode ser definido como:

... a reunião ordenada das várias partes que forma um todo, de tal sorte que elas se sustentam mutuamente e as últimas explicam-se pelas primeiras. As que dão razão às outras chama-se princípios e o sistema é tanto mais perfeito, quanto em menor número existam.

Numa definição mais sintética, Hugo de Brito Machado considera sistema o conjunto organizado das partes relacionadas entre si e interdependentes.

O Direito, enquanto ordenamento positivo, possui um número expressivo de leis, todas com aplicação, quer em âmbito restrito a determinado grupo de pessoas, quer dirigidas a toda a coletividade, possuindo forte conteúdo coercitivo, no caso de seu não cumprimento por aqueles a quem obriga (pessoas, empresas, associações, etc.)

Para a correta aplicação e interpretação das leis, faz-se mister o conhecimento profundo dos princípios albergados por cada norma, evitando polemizações e discussões estéteis acerca da letra fria da lei, que pode se dar a uma multiplicidade de interpretações, nem sempre corretas.

O desconhecimento por parte dos operadores do direito dos princípios os quais formam a pedra angular do Direito, conduzem a incorreta aplicação da lei, incidindo o aplicador do Direito em erro inescusável. As jurisprudências conflitantes a respeito de um mesmo tema e, por muitas vezes, emanadas do mesmo tribunal, são uma prova da afirmação acima declarada.

Antes de adentrarmos no estudo do tema proposto, acreditamos essencial firmar o conceito jurídico do que seja princípio, conceituando-o primeiramente no sentido leigo da palavra e, posteriormente, trazendo o entendimento jurídico da palavra.

Segundo definição dada pelo Novo Dicionário Aurélioº, a palavra princípio tem origem na palavra latina "principiu" a qual possui o significado de: causa primária, preceito, sendo a fonte ou causa de uma açăo.

O mesmo dicionário, ao dar o significado do termo princípios para a Filosofia, dita o seguinte conceito: Proposições diretoras de uma ciência, às quais todo desenvolvimento posterior dessa ciência deve estar subordinado.

O sentido filológico da palavra torna-se claro com $O$ esclarecimento proporcionado pelo pranteado dicionarista Aurélio Buarque de Holanda, autor do Dicionário Aurélio, tão conhecido de sucessivas gerações de brasileiros.

'CARRAZA. Roque Antonio. Curso de Direito Constitucional Tributário, 9 ed., São Paulo, Malheiros Editores, 1997, p. $31-35$

2 FERRERA, Aurélio Buarque de Holanda. Novo Dicionário Aurélio da Lingua Portuguesa Ed. Nowa Frontetra . Rio de Janeiro 1986 p. 1393 
Todavia, para a Ciência do Direito, o sentido do termo é mais específico, possuindo conotação própria.

Roque Antônio Carraza ${ }^{3}$ expressa, em rigorosa linguagem jurídica, um correto conceito de princípio jurídico.

(...) Princípio jurídico é um enunciado lógico, implícito ou explícito, que por sua grande generalidade, ocupa posição de preeminência nos vastos quadrantes do Direito e, por isso mesmo, vincula de modo inexorável, o entendimento e a aplicação das normas jurídicas com que eles se conectam.

E prossegue :

Evidentemente, os princípios são encontráveis em todos os escalões da 'pirâmide jurídica ". De fato, há princípios constitucionais, legais e até infralegais. Dentre eles, os constitucionais, sem dúvida alguma, são os mais importantes, já que sobrepairam aos outros princípios e regras (inclusive às contidas na Lei Máxima).

$(\ldots . .$.

.....O princípio cumpre função informadora dentro do Ordenamento Jurídico e, assim as diversas normas devem ser aplicadas em sintonia com ele. (....)

Estamos confirmando que o princípio influi na interpretação e na boa aplicação dos mandamentos constitucionais. repisamos que, se um mandamento constitucional aceitar várias interpretações, há de prevalecer a que estiver em sintonia com o princípio que lhe for mais próximo.

No mesmo sentido preleciona o notável jurista Celso Ribeiro Bastos ${ }^{4}$ ao ensinar que:

Princípio (...) é por definição, mandamento nuclear de um sistema, verdadeiro alicerce dele, disposição fundamental que se irradia sobre diferentes normas compondo-lhes o espírito e servindo de critério para sua exata compreensão e inteligência, exatamente por definir a lógica e a racionalidade do sistema normativo, no que lhe confere a tônica e the dá sentido harmônico. é o conhecimento dos princípios que preside a intelecção das diferentes partes componentes do todo unitário que há por nome sistema jurídico positivo.

Para Sacha Calmon Navarro Coêlho ${ }^{5}$ o que caracteriza os princípios é que näo estabelecem um comportamento específico, mas uma meta,

\footnotetext{
${ }^{3}$ CARRAZA. Op.cit., pag. $31-35$

${ }^{4}$ BASTOS, Celso Ribeiro. Curso de Direto Administrativo, 8 ed. São Paulo, Malheiros Editores, 1996, p. 545.

sCOELHO, Sacha Calmon Navarto. Comentatios a Constituicão de 1988 - Sistema Trbutário. 30 ed. , Rio de Janeiro, Forense 1991 , p. 106 
um padrão. Tampouco exigem condições para que se apliquem. Antes enunciam uma razão para a interpretação dos casos. Servem outrossim, como pauta para a interpretação das leis a elas se sobrepondo.

Da observação do posicionamento dos doutrinadores acima elencados, conclui-se que os princípios jurídicos são as grandes regras organizadoras da ordem geral do direito positivo.

São os princípios jurídicos que dão coesão e estrutura ao complexo jurídico instituído pelo Estado. Toda norma constitucional que se encontre em contradição com os princípios jurídicos previstos na Constituição Federal serão natimortas, ou seja nulas em efeitos e conseqüências.

\section{Função estrutural dos princípios constitucionais}

A Constituição de um pais tem por função ser a norma Suprema dentro do ordenamento jurídico de tal nação. Dentro deste entendimento, os princípios constitucionais atuam como linha mestra ou, utilizando uma figura de linguagem, seriam a coluna vertebral da organização jurídica estatal, atuando como um delimitador de proibiçôes, limitações e autorizações acerca das funções estatais.

Embora não haja hierarquia jurídica a subordinar as normas juridicas aos princípios jurídicos, torna-se claro que aquelas deverão sempre e sem. exceção ser interpretadas a luz destas, para que possuam validade e eficiência.

Além disso, fica claro que é do interior das normas constitucionais que deverão ser subsumidas todas as outras normas, as quais, obrigatoriamente, devem estar em consonância com suas orientaçôes.

No Estado Democrático de Direito os princípios constitucionais ganham ainda maior relevância posto que ambos são inafastáveis, disciplinando obrigatoriamente a ação dos indivíduos e das instituiçōes (tanto públicas quanto privadas), dos governantes e dos governados.

Os princípios tanto podem ser explícitos (quando expressamente declarados) ou ainda implícitos (quando encontra-se subentendido, sendo tácito o seu entendimento).

Ressalte-se que a importância do princípio não está relacionada ao fato de este ser implícito ou explícito, mas ao âmbito de abrangência de seu conteúdo, posto que as normas jurídicas não trazem sequer expressa sua condição de princípios ou regras. É o jurista que ao debruçar-se sobre elas identifica-as e hierarquiza-as. 
Diante dos conceitos apresentados acima, conclui-se que a violação de qualquer princípio jurídico constitucional, importa na mutilação inquestionável da Constituição e, por conseqüuencia, de toda a ordem jurídica.

A este respeito Carrazza assim se manifesta ${ }^{6}$ :

O jurista ao examinar o Direito, deve considerar as idéias que mais se aproximem da universalidade dos princípios maiores; com isto formará proposiçôes e terá verdades menos gerais. em seguida tomará as idéias que mais se aproximem por sua universalidade, das descobertas que acabou de fazer, concebendo novas proposições e continuando, desta maneira, sempre sem deixar de aplicar os primeiros princípios a cada proposição que descobrir. Descerá, então pouco a pouco, dos princípios gerais, às normas jurídicas mais particulares, caminhando, na medida do possível do conhecido para o desconhecido.

Realmente, mesmo sem detenças maiores, nota-se que o Direito, longe de ser um mero conglomerado de normas, é um conjunto bem estruturado de disposições que interligando-se por coordenação e subordinação, ocupam cada qual seu lugar próprio no ordenamento jurídico. (Ferrara). É precisamente sob este imenso arcabouço, onde se sobrelevam os princípios, que as normas jurídicas devem ser consideradas.

E, continua, invocando a lição de Luís Roberto Barroso:

$O$ ponto de partida do intérprete deve ser sempre os princípios constitucionais, que são o conjunto de normas que espelham a ideologia da Constituição, seus postulados básicos e afins. Dito de forma sumária,os princípios constitucionais são as normas eleitas pelo constituinte como fundamentos ou qualificações essenciais da ordem jurídica que institui. A atividade de interpretação da Constituição deve começar pela identificação do princípio maior que rege o tema a ser apreciado, descendo do mais genérico ao mais específico, até chegar à formulação da regra concreta que vai reger a espécie.

Concordando com a tese defendida por Kant de que os princípios constitucionais tem sua localização no ápice da pirâmide normativa, concluí-se que toda e qualquer norma que venha a surgir posteriormente à vigência da Constituição e que, possivelmente, entre em choque com os princípios, quer implícitos quer explícitos, delineados por esta, serão nulos, não gerando quaisquer conseqüências concretas no mundo material. 
Dentro desta linha de raciocínio, o princípio mais elementar, dentre os abrigados nas constituições democráticas, é o Principio da Legalidade, posto que já em sua origem histórica é ele que protege os cidadãos contra os atos arbitrários dos governantes. A proteção propiciada pelo Principio da Legalidade garante aos cidadãos a própria vigência do Estado Democrático de Direito.

A matéria tributária por sua importância possui princípios próprios, e específicos os quais serão agora abordados.

\section{Princípios constitucionais tributários}

O Direito Tributário brasileiro possui toda sua base e fundamento ancorado no Direito Constitucional (escrito e positivado), devendo obrigatoriamente ser disposto em consonância com os preceitos contidos neste.

Em verdade, os Princípios tributários contidos na Constituição Federal, possuem hierarquia interna, pois levam em conta sua importância e amplitude.Decorre naturalmente desta afirmativa, o fato que a não observância de um Princípio Constitucional pode ter conseqüências com diferentes graus de lesividade ao Estado Democrático de Direito.

Atentos a esta questão o legislador ao elaborar a Constituição da Republica Federativa do Brasil, promulgada em 1988, dedica um título especifico para a regulamentação do sistema tributário nacional.

O Título VI - denominado Da Tributação e do Orçamento - tem por finalidade instituir o poder de tributação, definir a forma como esta competência deve ser repartida entre as pessoas políticas da Federação (União, Estados, Distrito Federal e os municípios) e também as limitações relacionadas ao poder de tributar.

Possuindo 24 artigos (do art. 145 ao art. 169) este título se encontra dividido em dois Capitulos, quais sejam: Capítulo I - Do Sistema Tributário Nacional (arts. 145 a 162 ; que se subdivide em seis seções : Seção I Dos Princípios Gerais, arts. 145 a 149 ; Seção II - Das Limitações ao Poder de Tributar, arts 150 a 152 ; Seção III - Dos Impostos da União, arts 153 e 154 ; Seção IV - Dos Impostos dos Estados e do Distrito Federal, art. 155; Seção V - Dos Impostos dos Municípios, art. 156; Seção VI Da Repartição das Receitas Tributárias, arts 157 a 162) e Capítulo II - Das Finanças Publicas (arts 163 a 169, que se subdivide em Seção I - Normas Gerais, art. 163 e 164; e Seção II - Dos Orçamentos - arts. 165 a 169). 
E a primeira vez, que a Constituição dedica uma seção inteira de um capítulo às principais garantias do contribuinte contra a tributação indevida e injusta, determinando de forma clara e objetiva as limitações impostas pelo constituinte ao poder estatal de cobrar tributos.

As limitações constitucionais ao poder pertinente às pessoas politicas de tributar, encontram-se expressas no art. 150 da Constituição Federal, sendo que a análise deste artigo gera alguma polêmica entre os doutrinadores, principalmente, quanto a enumeração dos princípios constitucionais albergados pelo mesmo.

Para Sacha Calmon Navarro Coêlho ${ }^{7}$, as limitações Constitucionais ao poder de tributar tem fundamento nos três princípios vetores da tributação, a saber: Princípio da legalidade, da não-surpresa (que se subdivide em anualidade, anterioridade e postergação da vigência da lei tributária por um certo período) e irretroatividade da cobrança de tributos.

No entendimento de Roque Antônio Carraza ${ }^{8}$, seriam seis os Princípios Constitucionais pertinentes à matéria tributária que merecem destaque: o republicano, o federativo, o da autonomia municipal, o da anterioridade, o da legalidade e o da segurança jurídica.

Carraza considera que somente com a fiel observância destes princípios é que os tributos criados pelas pessoas políticas da Federação brasileira possuirão validade e eficácia. A correta aplicação destes princípios devem ser orientados no sentido de validar o supremo pressuposto jurídico : o princípio implícito da certeza do Direito, verdadeiro sobreprincípio que paira acima de todos os primados e rege toda a ordem jurídica, garantindo a segurança de todas as relações jurídicas existentes na sociedade humana.

Pinto Ferreira ${ }^{9}$ considera a existência de limites constitucionais de tributação, enumerando-os expressamente : a) princípio da legalidade (CF/88, art. 150$, I), b) princípio da reserva (CF/88art. $150,11 \mathrm{II})$, c) princípio da justiça (CF/ 88 , art. $5^{\underline{a}}$ e 170$)$ e o princípio da segurança (CF/88, art. $5^{\text {a }}$, XXXVI).

Aliomar Baleeiro ${ }^{10}$, mestre de todos os tributaristas, em sua obra Limitações Constitucionais ao Poder de Tributar, declara que, dentre as inúmeras limitações existentes ao exercício da atividade fiscal, apenas os princípios da legalidade, da anualidade do imposto e da capacidade contributiva revestem-se de caráter de generalidade sobre as diversas situaçóes.

\footnotetext{
COELHO,opcit: p. 268

CARRAZA, OPCit, p. 16

* PMTO FERRERA. Comentários à Constituição Brasileira. 5 vol. São Paulo Saraiva, 1992 p. 311 BALEEIRO, Aliomar. Limitacoes Constitucionais ao Doder de Triburar ,2 ed.1960 p. 13 
Salienta-se que, apesar das peculiaridades existentes na classificação dos diversos autores arrolados acima, ora restringindo, ora estendendo o rol de princípios constitucionais tributários, todos são unanimes em identificar o Princípio da Legalidade dentre eles.

\section{Do princípio da legalidade}

Segundo o Dicionário Jurídico, ${ }^{11}$ Princípio da Legalidade é oriundo do Direito Administrativo, o qual é definido como critério que informa toda a conduta da administração pública, no sentido de faze-la subordinar imperativamente à lei e ao ordenamento jurídico

Atualmente, o Estado exerce de forma centralizada as funções necessárias à obtenção do bem comum. Desta forma, a moderna estrutura estatal é responsável, entre outras coisas, pelo monopólio da criação das leis, da aplicação do jus puniendi, da defesa de seus cidadãos contra eventuais ataques de outros Estados soberanos e, principalmente, da cobrança de tributos para a arrecadação de recursos necessários a manutenção das atividades desenvolvidas por ele no campo social e econômico.

Ainda que a cobrança dos benefícios provenientes do Estado seja justa e necessária, esta não pode ser aplicada ao bel prazer do Administrador Público, pois incorreria em flagrante irregularidade, a qual poderia resultar na abolição do Estado de Direito e consequentemente na falência das instituições publicas existentes e do próprio direito objetivo.

Neste contexto, o Princípio da Legalidade consagra a garantia existente no Estado de Direito de que o particular não se encontra à inteira mercê do Príncipe(governante). O qual, num ato inesperado, poderia confiscar-lhe seu patrimônio ou alterar as regras para a cobrança de tributos a seu bel-prazer.

$\mathrm{Na}$ atualidade, a maioria dos países democráticos acolhem no bojo de suas Constituições o Princípio da Legalidade. Como exemplo, pode-se citar os seguintes países: Alemanha (art. 9a $)$, Áustria (art. 64) Cabo Verde (Art. 59, h) Suécia (art. 4ㄹ), Costa Rica (art. 121).

No Direito Brasileiro, o Princípio da Legalidade vem sendo acolhido de forma expressa desde a promulgação da primeira Constituição, ainda nos tempos do Império. $\mathrm{Na}$ Constituição de 1824, o referido princípio é descrito no art. 171; na de 1891, está expresso no art. 762, parágrafo 30 , em 1934,no art. 17, item VII, 1937, art. 13; 1946 art. 141, parágrafo 34; 
1967, em seus arts. 20, I e 150,parágrafos 2 e 29, na Emenda n. 1 (também chamada de Constituição de 1969) dedica o art. 19, I e o art. 153, parágrafos $2^{\mathrm{a}}$ e 29, e finalmente a Constituição Federal de 1988 que lhe dedica seus artigos 5a , II (trata do Princípio da Legalidade em termos gerais) e o artigo 150, I (especificamente acerca da legalidade tributária).

Os Códigos brasileiros, na atualidade, trazem de forma expressa a enunciação formal deste principio, sendo que em algumas áreas específicas a reserva legal prevalece para dar maior certeza e segurança jurídica nas relações interpessoais, como por exemplo no Direito Penal. (Art. $1^{\text {a }}$ - Não há crime sem lei anterior que o preveja. Não há pena sem prévia cominação legal, aplicação do princípio já albergado no Direito Romano; Nulla poena, sine prevea lege); em Direito Civil (na descrição dos modos de aquisição e perda de propriedade) e, principalmente, no Direito Tributário onde o princípio da legalidade reveste-se de reserva legal quase que absoluta (excetuando-se a majoração de Tributos, já prevista no art. $9^{a}$ do C.T.N.).

A respeito da origem histórica do Princípio da Legalidade, Sacha Calmo de Navarro Coêlho situa sua origem nas manifestações dos súditos ingleses no reinado de João-sem-terra, no século XI (1215), que originou a primeira Constituição escrita do mundo ocidental moderno ${ }^{12}$.

Tanto quanto o Direito Penal, o Direito Tributário registra ao longo de sua evolução histórica, a luta indormida dos povos para submeter o poder dos governantes ao primado da legalidade. $O$ jus puniendi e o jus tributandi foram, antanho, absolutos. Hoje todavia, se repete por toda parte : nullum tributum, nulla poena, sine lege. Assim o quer a consciência jurídica hodierna. Estado de Direito e legalidade de tributação são termos equivalentes. Onde houver Estado de Direito haverá respeito ao principio da reserva de lei em matéria tributária. Onde prevalecer o arbítrio tributário certamente inexistirá Estado de Direito. E, pois liberdade e segurança tampouco existirão.

Embora em sua origem a função primordial do Estado seja a defesa dos seus cidadãos e de seu território, não é prudente que este mesmo cidadão seja deixado à mercê do arbítrio do poder oriundo da organização estatal. No caso específico de matéria tributária, o Principio da Legalidade tem por função agir como o fiel da balança e evitar que o abuso dos poderes conferidos a este (o Estado) possam vir a torná-lo invencivel por aquele(povo), garantindo a defesa do cidadão contra atos obscuros e injustificados do poder Estatal. 
A análise acurada do Princípio da Legalidade, dá-nos subsídio para afirmarmos que todos os outros princípios que versam sobre matéria tributária são subprincípios que emanam dele.

O art. 150, I, da Constituição Federal de 1988, que determina o princípio da legalidade em matéria tributária, exige a existência de lei para a validade da criação e majoração dos tributos.

Por sua vez, o art. 97 do Código Tributário Nacional arrola quais os temas em sede de matéria tributária que obrigatoriamente devem submeter-se ao princípio da legalidade:

Art. 97 - Somente a lei pode estabelecer :

I - a instituição de tributos ou a sua extinção;

II - a majoração de tributos ou sua redução, ressalvado o disposto nos arts. 21 26, 39, 57 e 65;

III - a definição do fato gerador da obrigação tributária principal, ressalvado o disposto no inciso I do pár. $3^{a}$ do art. 52 e do seu sujeito passivo;

IV - a fixação da alíquota do tributo e da sua base de cálculo, ressalvado o disposto nos arts. 21, 26, 39, 57 e 65 ;

$\mathrm{V}$ - a cominação de penalidades para as ações ou omissões contrárias a seus dispositivos, ou para outras infrações nela definidos;

VI - as hipóteses de exclusão, suspensão e extinção de créditos tributários, ou de dispensa ou redução de penalidade

$\S .1^{a}$ - Equipara-se a majoração do tributo a modificação de sua base de cálculo que importe em torná-lo mais oneroso.

$\S .2^{a}$ - Não constitui majoração de tributo, para os fins do disposto no inciso II deste artigo, a atualização do valor monetário da respectiva base de cálculo.

A leitura do artigo acima demostra a amplitude da aplicação prática do princípio da legalidade. Portanto, é essencial para sua correta aplicação, definir qual é o sentido exato da expressão lei, utilizada pelo legislador constituinte em relação ao Direito Tributário. Também sobre esta questão os doutrinadores pátrios divergem.

Ives Gandra Martins ${ }^{13}$ defende a validade de utilização de medida provisória na instituição e majoração de tributos, por entender que o texto Constitucional não faz vedação expressa a sua utilização e, a existência da possibilidade de transformação desta em lei, possibilita sua aplicação na seara tributária.

\begin{tabular}{lr}
${ }^{13}$ MARTINS. Ives Gandra.Comentários à Constituição do Brasil 6 vol. São Paulo, Saraiva 1990 & p. 146 \\
\hline 333
\end{tabular} 
Yonne Dolacio de Oliveira, ${ }^{14}$ considera que para o Direito Tributário, a expressão lei, refere-se aos atos normativos relacionados no art. 59 da Constituição Federal ${ }^{15}$

Data vênia, apesar do enorme valor destes juristas citados para o Direito Tributário, seus entendimentos não nos parece que sejam os mais corretos.Comungamos pois, da posição defendida pela maioria dos doutrinadores acerca da natureza "strictu sensu" da expressão. Dentre estes citamos:

Alberto Xavier, ${ }^{16}$ nos ensina que o conceito de lei refere-se sem dúvida à lei ordinária dimanada do Poder Legislativo.

Do mesmo entendimento é Sacha Calmon de Navarro Coêlho ${ }^{17}$, quando afirma:

Entre nós, como está na Constituição de 1988, o princípio da legalidade da tributação, exige lei em sentido formal(instrumento normativo proveniente do Poder Legislativo) e material (norma jurídica geral e impessoal, abstrata e obrigatória).

A legalidade da tributação, dizia Pontes de Miranda, significa o povo se tributando a si próprio. Traduz-se como o povo autorizando a tributação através dos seus representantes eleitos para fazer leis, ficando o Príncipe, o chefe do Poder Executivo - que cobra os tributos - a depender do Parlamento.

Também Carrazza ${ }^{18}$ analisa o assunto chegando a idêntica conclusão :

(...) uma interpretação sistemática do Texto Magno revela que só a lei ordinária (lei em sentido orgânico-formal) pode criar ou aumentar tributos. Dito de outro modo, só a lei - tomada na acepção técnico-específica de ato do Poder Legislativo, decretado em obediência aos tramites e formalidades exigidos pela Constituição - é dado criar ou aumentar tributos.

Deriva deste entendimento o Princípio da Estrita Legalidade em matéria tributária, a qual fornece duas ordens de garantias ao contribuinte uma formal e outra material.

\footnotetext{
1. OLIVEIRA, Yone Dolácio de. Curso de Direito Tributário, 2 vol. Belém, CEIUP, 1993 p. 142

15. "Art. 59 - O processo legislativo compreende a elaboração de :

1. emendas a Constituiça ;

II - leis complementares;

III - leis ordinarias ;

IV - leis delegadas;

$V$ - medidas provisonias;

V1 - decretos legishativos

resolucocs.

15. XAVIER, Alberto. Os Princípios da Legalidade e da Tipicidade da Tributação São Paulo, Ed. Revista dos Tribunais, 1978 p. 22

"COElHO. op. cit, p. 286

CARRAZA, op. cit. pág. 171 .
} 


\section{Estrita legalidade em matéria tributária}

Embora todos os doutrinadores concordem acerca da existência do princípio da Estrita Legalidade e de sua importância basilar no Direito Tributário, algunsn autores utilizam-se de nomenclatura diferente para defini-lo.Alberto Xavier refere-se a ele através da denominação de Princípio da Reserva Absoluta de Lei Formal. Pinto Ferreira denomina-o de Principio da Legalidade Tributária. Geraldo Ataliba, Celso Ribeiro Bastos, Roque Antônio Carrazza e Sacha Calmon preferem a terminologia Princípio da Estrita Legalidade.

Consideramos a expressão Estrita Legalidade a mais adequada, por exprimir de forma clara o significado do Princípio, sem utilizar-se de piruetas gramaticais.

O Direito Tributário é o ramo do Direito mais exigente na cobrança da necessidade de aplicação do Princípio da Legalidade, exigindo para a aplicação da lei tributária uma reserva absoluta da lei formal.

Em matéria tributária, a obrigação sempre há de se originar de lei. Enquanto outros ramos do Direito, seja este público ou privado, podem utilizar-se de outras fontes para a solução dos conflitos, "como por exemplo: os usos e costumes, as decisões judiciais, os acordos particulares e a doutrina. No Direito Tributário somente a lei pode ser fonte e causa da obrigação tributária. É a aplicação do antigo brocardo jurídico: obligatio nascitur ex lege.

Celso Ribeiro Bastos, ${ }^{19}$ ao comentar sobre a importância deste princípio, invoca Fonrouge que assim se exprime:

Um dos princípios essenciais do Estado moderno é o da legalidade da tributação - também conhecido por reserva da lei - que a doutrina considera como regra fundamental do direito público.

Remonta épocas bastante remotas a exigência de que as contribuições devem ser consentidas pelos representantes do povo. $\mathrm{Na}$ Grã-Bretanha, manteve-se vigente sem interrupção, sendo adotada pela Constituição dos Estados Unidos da América de 1787. Na França, caiu em desuso nos séculos XV e XVI, tendo sido restabelecida entretanto pela declaração dos direitos do homem de 1789 e na Argentina - como nos demais países que receberam influência da revolução francesa -, data da revolução de maio de 1810.

19ASTOS, Celso Ribeiro. Curso de Direito Financeiro e de Direito Tributário São Paulo, Saraiva, 1995 p. 107 
Da importância deste princípio tem-se idéia pelo fato de que as Constituições escritas o incluem no texto, pois na organização democrática se reafirma o conceito segundo o qual só o parlamento - como representante do povo pode criar contribuições.

Daí que a maioria das constituições modernas o consagra especificamente.

Alberto Xavier defende que o Princípio da legalidade no Estado de Direito não é á, pois mera emanação de uma idéia de autotributação, de livre consentimento dos impostos, antes passa a ser encarado por uma nova perspectiva, segundo a qual a lei formal é o único meio possível de expressão da justiça material".

Dito de outra forma, no Estado de Direito o princípio da legalidade tributária é, para os cidadãos, o único meio válido para a revelação e garantia da justiça tributária. É a lei que garante ao cidadão a liberdade de agir, ao determinar que o Estado não poderá obrigá-lo a fazer ou deixar de fazer algo senão em virtude de lei ${ }^{20}$.

Roque Antônio Carazza define o Principio da Legalidade como uma das mais importantes colunas sobre as quais se assenta o edificio do Direito Tributánio.

Sacha Calmon - na obra Comentários à Constituição de 1988, Sistema Tributário - entende que o Princípio da Legalidade encontra justificativa no fato de que todo tipo de tributação deve ser decidida, não pelo chefe do governo, mas pelos representantes do povo, livremente eleitos para fazer as leis, ou seja, numa ultima análise, os tributos a serem pagos pelo povo de um determinado Estado devem ter sua origem nos interesses e necessidades do próprio povo, não simplesmente no interesse tributador do governante.

A Constituição Federal de 1988 delimita que a competência para criar ou aumentar tributos é exclusiva do Poder Legislativo em seus vários níveis (Nacional, Estadual, municipal ou distrital), sendo considerado também uma forma de reforçar a garantia de proteção à propriedade privada.

Para criar ou majorar tributos a forma legislativa válida é a lei ordinária. As únicas exceçôes possíveis à esta determinação legal são expressamente previstas na Constituição, quais sejam: empréstimos compulsórios, impostos residuais da União, e as contribuições sociais que se encontram elecadas no art. $195, \S .4^{\mathrm{a}}$ de nossa Constituição.

\footnotetext{
A Administraçäo Pública a contrário, somente poderá fazer o que a lei lhe permite É a aplicação do princípio juridico "prohibita intelligentur quod non permisium ". 
Através da análise do princípio da estrita legalidade, conclui-se que todo e qualquer valor que venha a ser cobrado do contribuinte, seja através da criação de novo tributo ou do aumento do valor de tributo já existente, só pode sê-lo através de lei ordinária, editada pela pessoa política investida de competência para este ato através da Constituição.

Porém, para que a norma seja válida não basta que seja qualquer lei ordinária, deve sim atender a certas exigências. Faz-se imprescindível que a lei delimite de forma concreta e exaustivamente, todos os elementos essenciais ${ }^{21}$ do fato tributável.

Isto significa que a lei há de descrever abstratamente o fato cuja ocorrência fará surgir o dever de pagar o tributo (hipótese de incidência), estabelecer a base de cálculo, isto é aquele aspecto mensurável da hipótese de incidência sobre o qual incidirá a alíquota (que também deverá vir prevista).

Além, é claro, de indicar o sujeito passivo (quem deverá pagar o tributo).e declarar de forma expressa o sujeito ativo, (normalmente este é a pessoa jurídica de Direito Público que institui o tributo).

O Princípio da Estrita Legalidade exige também a existência de mecanismos revisores da legalidade da tributação, tanto na esfera administrativo quanto na esfera judicial.

No Brasil, o contribuinte tem, em relação à Fazenda Pública duas ordens de garantias: uma material, na medida em que este só pode ser compelido a pagar tributos que tenham sido criados por meio de lei ordinária (de pessoa política competente) e, outra garantia, de ordem formal, já que o contribuinte tem garantido seu direito de apelar ao Poder Judiciário, para que este verifique da legalidade da cobrança tributária promovida pela Administração fazendária

Conclui-se então, que a garantia formal (o aceso ao Poder Judiciário, para a resolução de questões contenciosas tributárias), é o que torna viável a aplicação da garantia material (lei escrita e específica editada por pessoa política competente, que possui a finalidade de criar ou majorar tributos).

\section{Conclusão}

Ante o exposto no presente, o Princípio da Estrita Legalidade implica em o Estado-Legislador obedecer os ditames legais imposto pelo Estatuto Supremo, i.e., a norma jurídica tributária deve ser considerada sobre seu aspecto material e formal. Material no sentido de editada pela pessoa juridica competente e formal no sentido de se observar a forma prescrita em lei.

21 "Na definiçio de Carrazza são elementos essenciais dos tributos todos os elementos que de algum modo influem no an, e no quantum da obrigaçáo tributária. CARRAZZA, op. cit. pág. 172 
A proteção do contribuinte contra os desmandos do Estado na cobrança de tributos é garantida por meio da autotributação, ou seja, que estes somente poderão vir a ser cobrados, se instituídos por representantes eleitos pelo povo que exprimem a vontade deste.

$O$ Princípio da Estrita Legalidade exerce a função de filtrar os tributos que não atendam esta exigência básica. O surgimento deste princípio (na Grã- Bretanha, Carta Magna de João sem Terra,1215; e na Constituição dos Estados Unidos da América de 1787) encontra-se intimamente ligado ao reconhecimento pelo Estado de que a vontade popular é elemento intrínseco do Estado Democrático de Direito. Este conceito é a base do Estado Moderno.

É o Princípio da Estrita Legalidade que garante a segurança jurídica essencial na relação entre o contribuinte e o Fisco, protegendo o cidadão das arbitrariedades que porventura o Estado possa a vir intentar, como por exemplo a bitributação e o confísco de bens .

O legislador constituinte de 1988 , reconheceu a extrema importância do mesmo ao prever de forma explicita que nenhum tributo pode vir a ser criado ou aumentado sem existência de lei prévia que o estabeleça. Neste ponto houve uma notável evolução em comparação à Constituição anterior, a qual apresentava ressalvas quanto a possibilidade de aumento dos tributos.

A não obediência ao art. 150 , inc. I da Constituição Federal causa maiores prejuízos ao Estado democrático de Direito que a desobediência pura e simples de uma norma jurídica tributária, pois conforme lição emanada de Celso Antônio Bandeira de Mello, a ofensa à um princípio é muito mais grave que a ofensa a uma lei, porque aqueles alicerçam a ciência jurídica.

Em suma, quer nos parecer que não há que se falar em Direito Tributário com segurança ao contribuinte sem o Princípio da Estrita Legalidade, que é o Sol iluminador de nosso Ordenamento Jurídico. Elimine-se este Princípio em matéria tributária e ruirá, com certeza, todo o chamado Estado Democrático de Direito.

\section{BIBLIOGRAFIA}

ATALIBA, Geraldo (Coord.). Elementos de Direito Tributário. São Paulo: Revista dos Tribunais, 1978

BALEEIRO, Aliomar. Limitações Constitucionais ao Poder de Tributar, $2^{\circ}$ ed. rev. e atual. Rio de Janeiro, Forense, 1960

BARROSO, Luís Roberto. Interpretação e aplicação da constituição: fundamentos de uma dogmática constitucional transformadora $4^{\circ}$ ed. ver. E atual. São Paulo: Saraiva, 2001 
BASTOS, Celso Ribeiro. Curso de Direito Financeiro e de Direito Tributário, 4ํ ed. São Paulo. Saraiva, 1995

lo : Celso Bastos Editor

Hermenêutica e interpretação Constitucional São Pau-

BECKER, Alfredo Augusto. Teoria Geral do Direito Tributário São Paulo Saraiva, 1972

BONAVIDES, Paulo. Curso de Direito Constitucional. São Paulo. Malheiros Editores, 1994. CAMPOS, Antônio J. Interpretação, Hermenêutica e Exegese no Direito Tributário. São Paulo. José Bushastsky, 1977

CARRAZZA, Roque Antônio. Curso de Direito Constitucional Tributário 9o.ed. Rev.. e ampl. São Paulo Malheiros Editores,1997

COELHO, Sacha Calmon Navarro. Comentários à Constituição de 1988 : Sistema Tributário. Rio de Janeiro Forense, 1991

COELHO., Inocêncio Mártires. Interpretação Constitucional. Porto Alegre: Sérgio Antônio Fabris Editor, 1997.

CRETTELLA Júnior, José. Curso de Direito Tributário Constitucional Rio de. Janeiro Forense Universitária, 1993

DINIZ, Maria Helena. Conceito de Norma Jurídica como problema de essência. 3 ed. São Paulo : Saraiva, 1999

ESPÍNDOLA, Ruy Samuel. Conceito de Princípios Constitucionais $2^{\circ}$ ed. ver atual. e ampl. São Paulo : Ed. Revist dos Tribunais, 2002.

FERREIRA, Pinto. Comentários à Constituição Brasileira. 5 vol. São Paulo Saraiva, 1992 Curso de direito Constitucional. São Paulo: Saraiva. 1993 FRANÇA, R. Limongi. Hermenêutica Jurídica. 3 ed. rev. São Paulo: Saraiva, 1994. HÄBERLE, Peter. Hermenêutica Constitucional. Porto Alegre: Sérgio Antônio Fabris Editor, 1997.

MARTINS, Cláudio. Normas Gerais de Direito Tributário. 2. ed..rev. e ampl. Rio de Janeiro Forense 1969

MARTINS, Ives Gandra. Curso de Direito Tributário, Belém, CEJUP, vol, I e II, 1993 MORAES. Alexandre de. Direito Constitucional. 11 ed. São Paulo: Atlas, 2002 NOGUEIRA, Ruy Barbosa Curso de Direito Tributário. 5. Ed.. Reescrita e atualizada Belo Horizonte. 1980

PEIXINHO, Manuel Messias. GUERRA, Isabella Franco. NASCIMENTO FILHO, Firly (org.) Os Princípios da Constituição de 1988. Rio de Janeiro : Lumen Juris. 2001

SIDOU, J.M. Othon. Dicionário Jurídico. Forense Universitária , 1995 SILVA, José Afonso da. Curso de Direito Constitucional Positivo. São Paulo: Malheiro Editores. 1994

TEIXEIRA, J. H. MEIRELES. Curso de direito constitucional Rio de Janeiro : Forense Universitária. 1991

XAVIER, Alberto. Os Princípios da Legalidade e da Tipicidade da tributação. São Paulo, Ed. Revista dos Tribunais, 1978 